\title{
Indicators of climate: Ecrins National Park participates in long-term monitoring to help determine the effects of climate change
}

Richard Bonet, Fabien Arnaud, Xavier Bodin, Michel Bouche, Isabelle Boulangeat, Philippe Bourdeau, Martial Bouvier, Laurent Cavalli, Philippe Choler, Anne Delestrade, Cédric Dentant, Dominique Dumas, Laurent Fouinat, Marie Gardent, Sébastien Lavergne, Emmanuel Naffrechoux, Yann Nellier, Marie-Elodie Perga, Clotilde Sagot, Olivier Senn \& Wilfried Thuiller

Keywords: indicators, long-term observation work, climate change

\section{Abstract}

In accordance with their mission and as part of their long-term observation work, Ecrins National Park (NP) is making important contributions to the study and monitoring of phenomena related to climate change. Its work takes information collected at different meteorological stations and supplements it with analyses of vegetation changes through aerial and satellite images, measuring and monitoring of glaciers, and interdisciplinary programmes focused on high-altitude lakes, mountain pastures and indicator species.

Through its mission and long-term observations, Ecrins NP (http://www.ecrinsparcnational.fr/) contributes to the environmental surveillance of many ecosystems. Working within many different networks and in partnership with various research teams, the park participates in the development of a better understanding of the important changes taking place.
Profile

Protected area

Ecrins National Park

Mountain range

Alps

Country

France

\section{Long-term observation network}

"Many different observation systems are needed to understand the consequences of changes in climate," explains Richard Bonet, head of scientific research at the park. "Even if the initial findings seem straightforward, it is only through combining physical and biological data that we can really achieve robust results."

Physical measurements at the forefront

Physical measurements, carried out either by automated devices or by park employees, make up the first research focus.

Established in 2002, the Lauvitel meteorological station (Figure 1) helps to complete a national network of weather stations by adding measurements at high elevations (Dumas et al. 2011). Automated photographic monitoring allows the national park (NP) to keep track of events that affect the lake and the basin above (snow cover, lake ice cover, ecosystem phenology and vegetation dynamics etc.), see Figure 2.

In addition to climate data the European Monitoring and Evaluation Programme (EMEP) observation station at the Casset, near the Col du Lautaret, also collects data on air pollution. Information collected at the site is automatically transmitted to the NP's database. The data is compiled on a weekly basis by a park employee and transmitted to the various laboratories involved in the programme.

Phénoclim citizen science programme

Pheno as in phenology and clim as in climate, Phénoclim is a scientific and educational project estab-

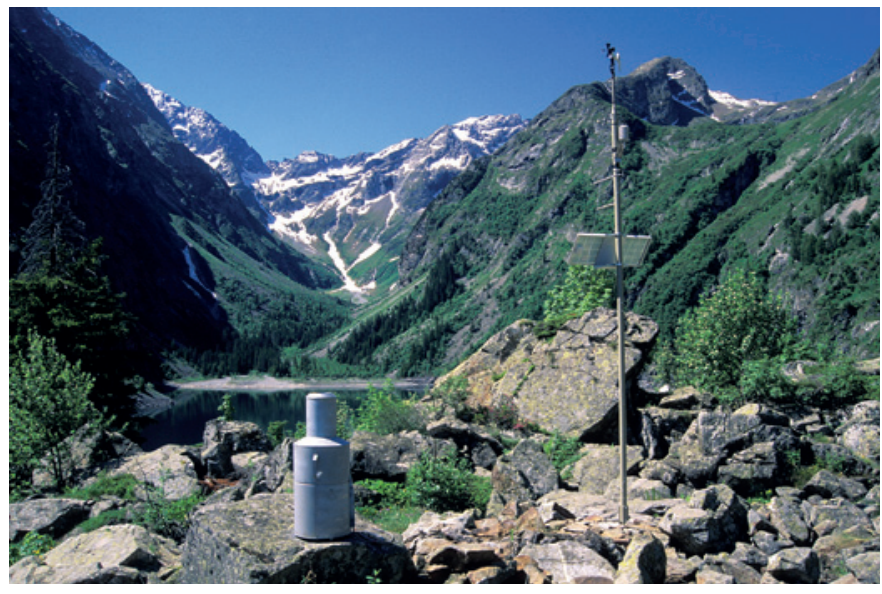

Figure 1 - Lauvitel meteorological station. (C) Ecrins NP Denis Fiat

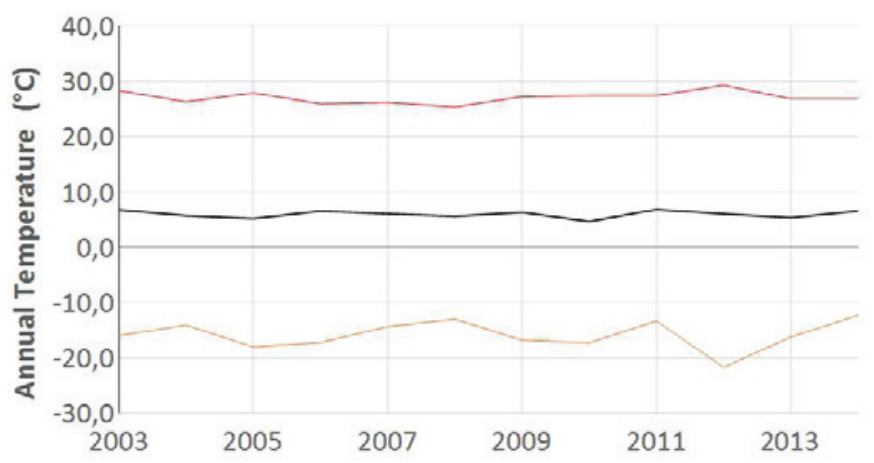

- Avg. temp. (Tg) - Min. temp. (Tn) - Max. temp. (Tx)

Figure 2 - Annual average temperatures observed at the Lauvitel meteorological station between 2003 and 2013. (C) IGA 2014 Dumas Dominique 


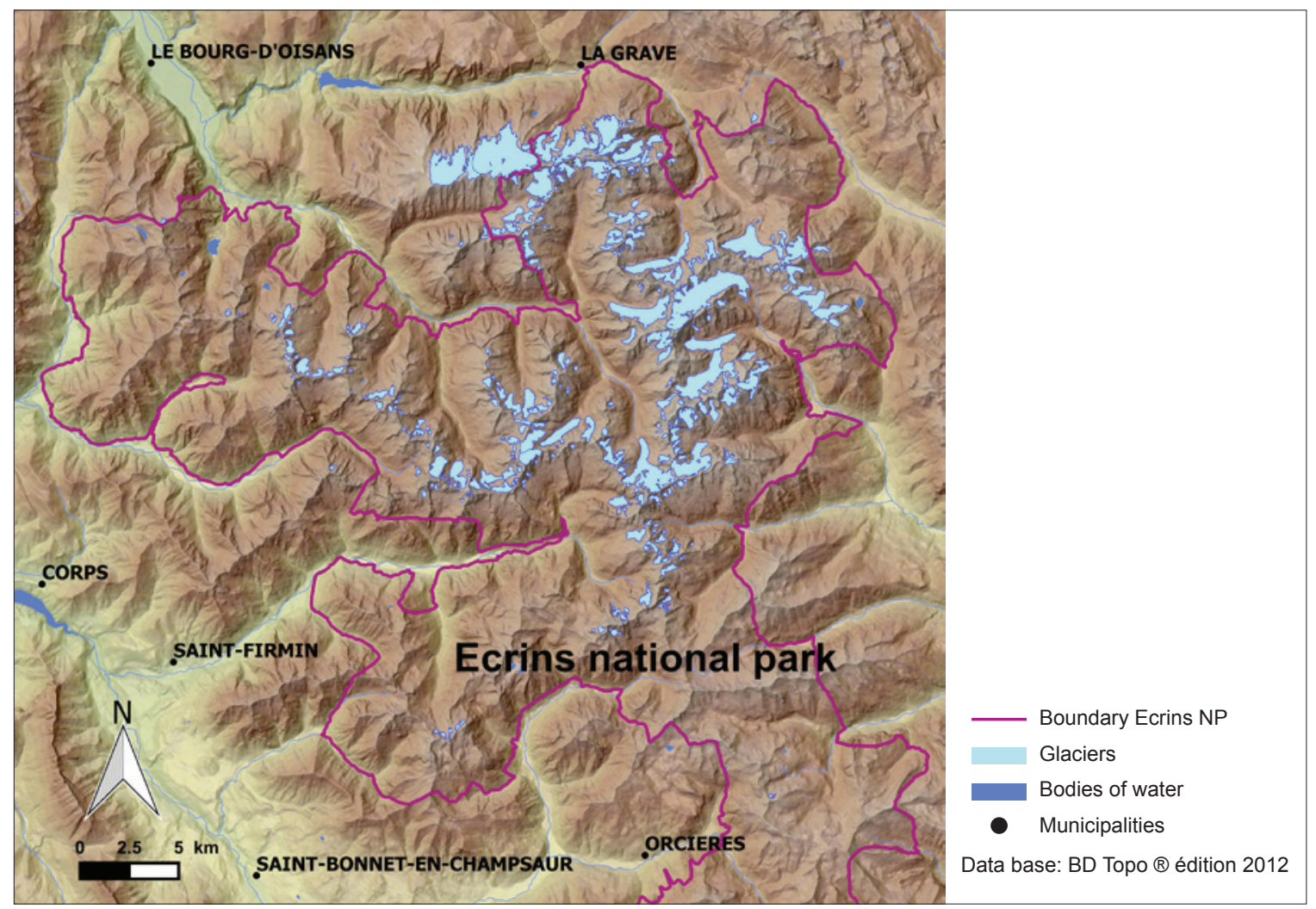

Figure 3 - Glaciers in Ecrins NP. (C) Edytem Savoie 2012 Marie Gardent / (C IGN 2015

lished in 2004 and originally piloted by the Alpine Ecosystems Research Centre (CREA, http://www. creamontblanc.org/) based in Chamonix, France. The programme invites the public to help measure the impact of climate change on mountain flora and fauna. In the course of 10 years nearly 5000 people have participated in the Phenoclim project: private individuals, professionals in environmental science, students and teachers, organizations and businesses.

In 2004 Ecrins NP also partnered with CREA to set up a monitoring station at the NP Visitor Centre in Vallouise, where participants can carry out their phenology and snow cover observations. Since 2013 two other observation points have been installed, including a unique high-altitude station near the Refuge du Vallonpierre at 2270 meters.

Finally, in 2014, Ecrins NP helped CREA to modernize the Phénoclim database by improving the data input system, redesigning the Phénoclim website and developing a mobile application that allows participants to record observations directly on their smartphones.

\section{Both white and green!}

Melting glaciers, the evolution of snow cover and the growth of grass: long-term monitoring to help understand the evolution and anticipate future management measures.

As the climate evolves, glacier monitoring continues to be the most clear evidence for tracking ongoing change. The park has put in place a protocol for measuring the retreat of multiple glaciers in the range, as well as a protocol for calculating the mass balance of the NP's largest glacier, the Glacier Blanc.

Measuring the spatial extent of glaciers is the oldest monitoring method. Traditionally calculated using a measuring tape, the distance from a fixed point to the tongue of a glacier is now measured using laser telemetry. Glacial extent monitoring is currently in place for five of the glaciers in the Ecrins massif: Glacier Blanc, Glacier Noir, Glacier de La Selle, Glacier du Sélé, and the longest-monitored glacier, the Glacier de La Pilatte (Figure 3). The very first observations of the Glacier de La Pilatte were recorded by the Mountain Restoration Service (RTM) in 1920.

Since 1986 the tongue of the Glacier Blanc has receded $726 \mathrm{~m}$ or an average of $26 \mathrm{~m}$ per year. Simple distance measures have allowed researchers to estimate that the surface area of glaciers throughout the Ecrins range has dropped from $100 \mathrm{~km}^{2}$ in 1986 to $69 \mathrm{~km}^{2}$ today.

By itself glacial retreat is not a comprehensive indicator of glacier dynamics. Other measures are necessary to calculate the evolution of glacial mass. Along with its partner institutions (Laboratoire de Glaciologie et Géophysique de l'Environnement (LGGE, http://lgge.osug.fr/) and the National Research Institute of Science and Technology for Environment and Agriculture (IRSTEA, http://www. irstea.fr/linstitut/nos-centres/grenoble), Ecrins NP has applied complex methods for calculating mass balance in their monitoring of the Glacier Blanc, the 


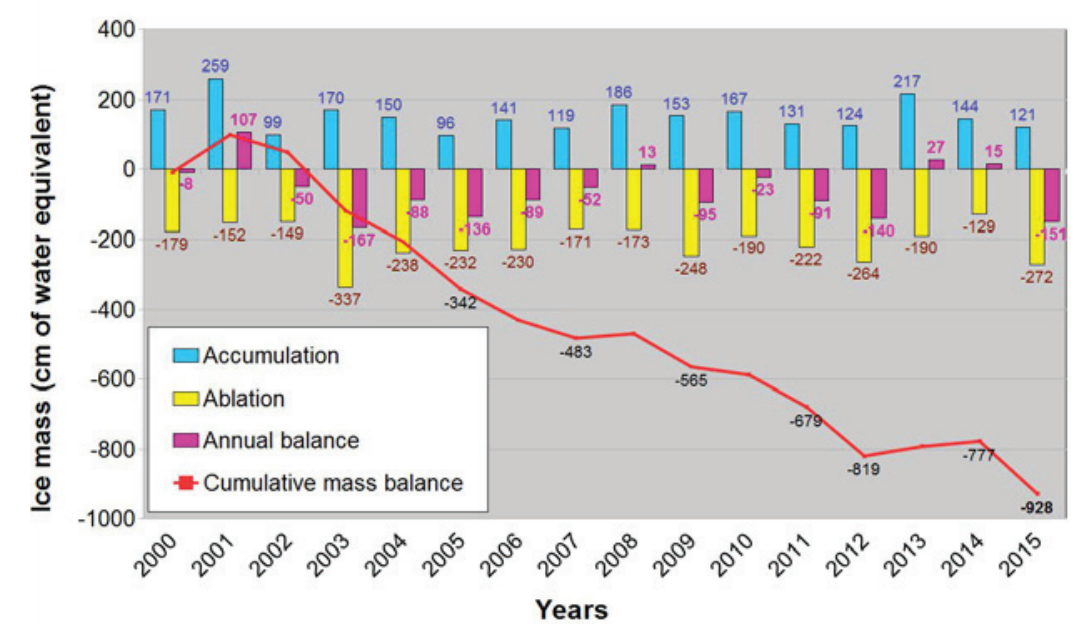

Figure 4 - Glacier Blanc mass balance. (C) Ecrins NP 2015 Bouvier Martial

Glacier de Laurichard (a rock glacier) and the Glacier Noir, see Figure 4 \& 5 .

The Glacier de Sarennes, which has nearly disappeared, was one of the first glaciers in the Alps for which annual mass balances were estimated. The calculations were made by the Laboratoire de Glaciologie et Géophysique de l'Environnement, a long-term partner of Ecrins NP. The data collected by Ecrins NP have been combined with the statistics from other countries and help to better understand the evolution of glacial masses around the world. Ecrins NP staff is also keeping a photographic record of some of the range's glaciers to conserve a testimonial of glacial extent over the years.

The Glacier de La Pillate in 1921 and 2003

In addition to fuelling to scientific studies, measurements of changing glaciers can also provide important information to climbers and hikers, see Figure 6: Can anyone remember when the glacier nearly reached the but... and now it is $50 \mathrm{~m}$ below it? And what about this mountaineering route that originally began on the glacier, but now requires several difficult pitches of climbing on glacier-polished rock to access it?

\section{Alpinism and climate change}

Confronted with the realities of climate change, mountain professionals encounter an increasing number of challenges that require adaptation of their practices (Figure 7). Alpinism is highly affected by many changes: in practices and equipment, in the seasonality of favourable conditions, the nature of activities, the ways of obtaining information and the expansion of practicable terrain (Bourdeau 2006, 2009).

A current study in cultural geography hopes to document these changes through the collection of testimonials on the adaptation of mountain practices in the face of an evolving environmental and climate change. This project is the initiative of Philippe Bourdeau and made possible by the Social

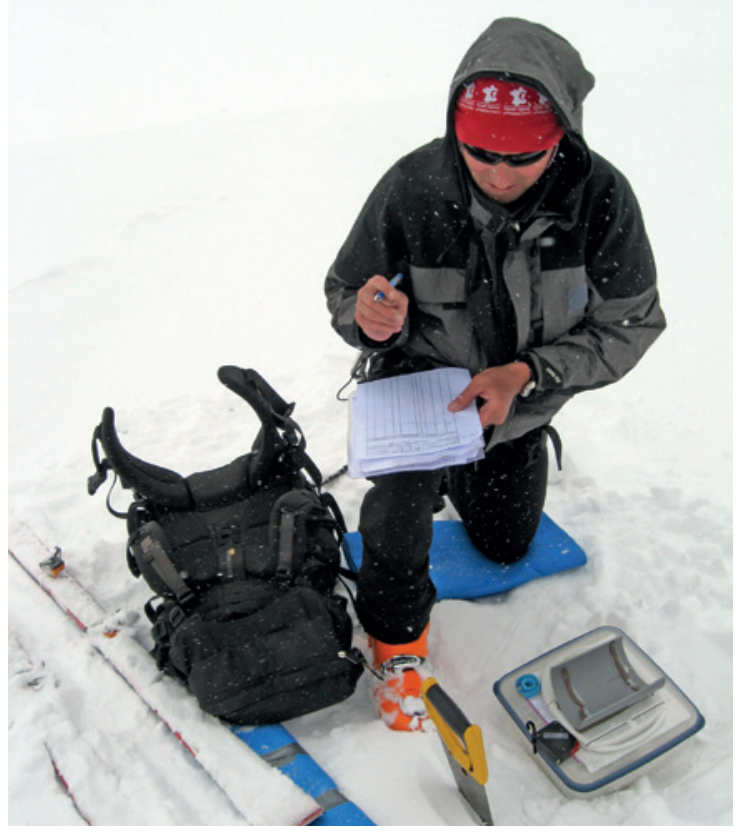

Figure 5 - Glacier monitoring. (C) Ecrins NP Cyril Coursier

Science Research Laboratory (PACTE, http://www. pacte-grenoble.fr/) and the ODDT, association in partnership with Ecrins National Park, the Alpine Orality Centre (Centre de l'Oralité Alpine, Conseil départemental des Hautes-Alpes) and the LTER Alpes (Long Term Ecology Research Alpes, also called Zone Atelier Alpes, of the French National Centre for Scientific Research (CNRS)).

This study has led to the production of both video and audio documents.

\section{Monitoring snow cover}

"In parallel with glacier monitoring, the NP is also following the evolution of snow cover in the area through the use of satellite data. In this way it has been possible for us to visualize the snow cover of the entire territory of the park on a month-bymonth basis since 2001," explained Richard Bonet. "This global vision of snow cover emphasizes low and high snow years. The measurements also allow us to recognize the region's photosynthetic activity in both spring and summer. When the snow melts, it is possible to identify when grass will begin to grow, when its production will be at a maximum and at what date it will dry out."

These indicators are essential in understanding the consequences of snow cover duration and summer droughts on the productivity of grasslands on the valley floor and on high elevation pastures (Choler 2015). These grasslands constitute an essential forage resource for grazing livestock, a flagship activity in local agriculture.

Monitoring devices have been installed in mountain pastures (Figure 8) to supplement and support the satellite data. Several sites are equipped with webcams and optical devices that track both snowmelt dynamics and vegetation growth and senescence. 
Clotilde Sagot, environmental technician in the scientific research branch of the NP, works on this project with Philippe Choler's team at the Laboratoire d'Ecologie Alpine (LECA, http://www-leca.ujf-grenoble.fr/). She explains that these monitoring devices function "like satellites, but on a much more local scale. This equipment allows us to analyse changes in the snow cover duration, the growth of grass and the speed at which these processes are bappening." The instruments and the data collected in this project are a part of the Franco-Italian project e-PHENO (Alcotra collaboration programme) focused on plant and ecosystem phenology.

\section{Environments and indicator species}

Observed shifts in species distributions and phenology can in general be explained in part by changes in climate, and in part by changes in land-use practices. These two phenomena are often linked, sometimes even by a causal relationship. For example, a period of drought in an alpine pasture could lead to uncommon practices including night-time grazing, added pressure, or grazing in normally unused areas. The objective of the monitoring put in place is to increase understanding of how the system functions through the recording of physical, biological and sociological data. These measurements enable understanding of the relative importance of consequences due to climate and those due to use (pastoralism, tourism, agriculture, forest management, etc.).

Different projects study these changes in three distinct zones: mountain pastures, lakes and high-altitude environments.

\section{Mountain pastures and dialogue}

Following droughts in 2003 and 2005, Ecrins NP put in place a programme called Alpine Pasture Sentinel (Alpages Sentinelles). The programme involves many scientific partners, pastoral technicians and land managers. These actors collect data within their field of expertise, allowing for analysis of changes induced by episodes of drought. "The programme works as a tool providing belp with analysis and decision-making in relation to processes involving the climate, the environment, pastoral practices and livestock farming systems." (Dobremez et al. 2014).

The primary measurements collected are meteorological (rainfall, duration of snow cover), biological (evolution of vegetation, annual production) and landuse related (intensity of grazing, length of grazing season). Nine sites have been selected to observe the consequences of climate change and pastoral practices on alpine pastures.

\section{Vegetation transects}

More than 30 permanent vegetation transects are in place throughout mountain pastures in Ecrins, many of which have been established for over 20 years (the oldest was established in 1986). This long-term moni-
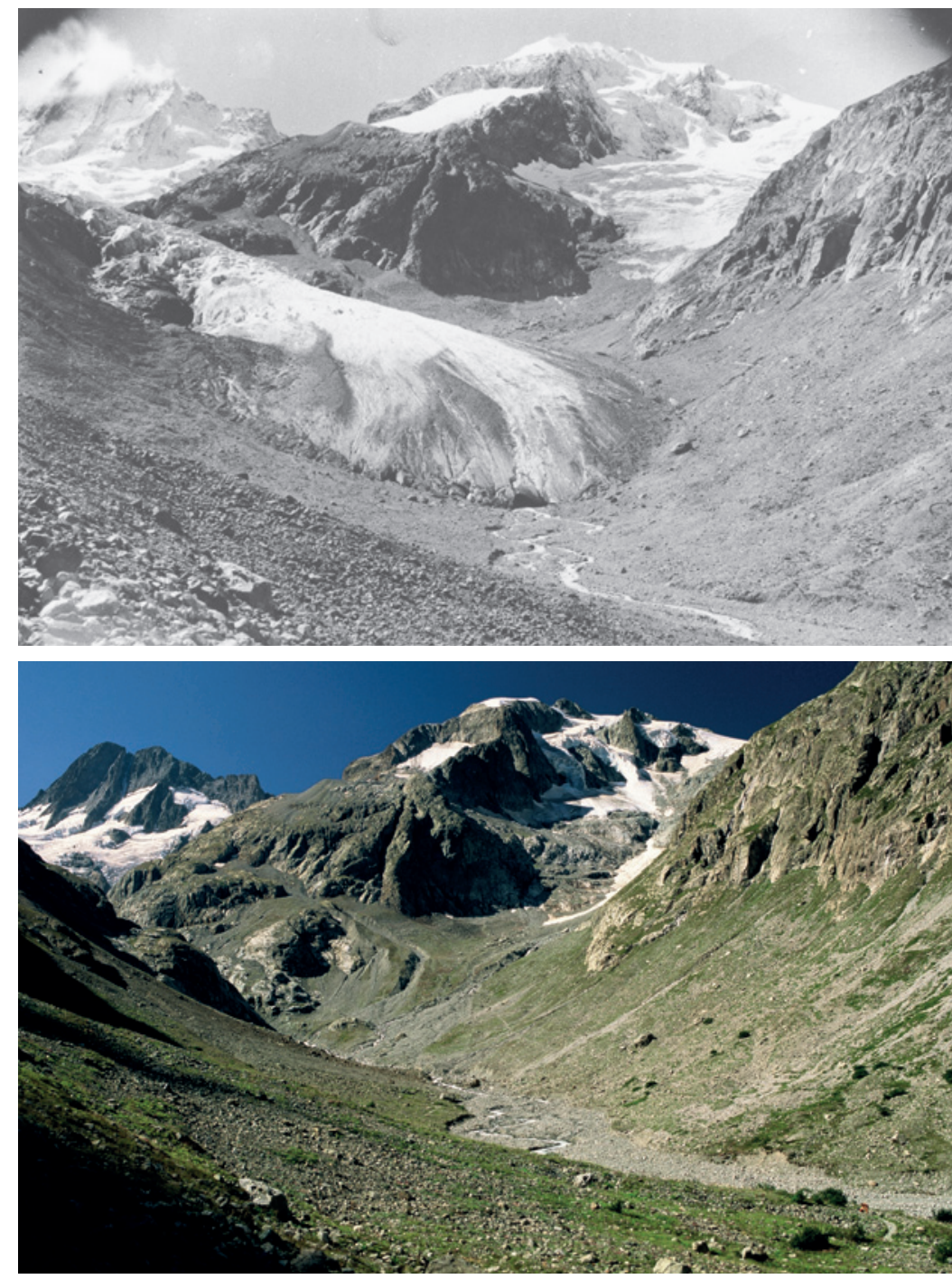

Figure 6 - The Glacier de La Pillate in 1921 (top) and 2003 (bottom). (C) Archives départementales de l'Isère (top) and Ecrins NP Emmanuel Thibert (bottom)

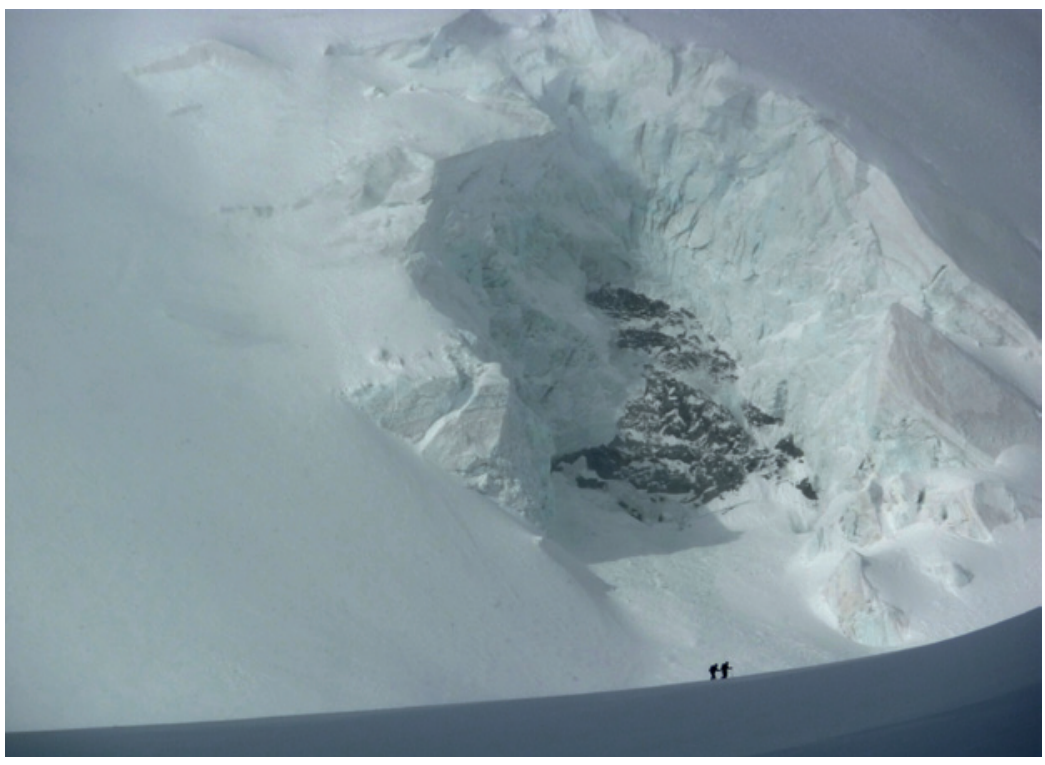

Figure 7 - Ski tourism in the NP. (C) Ecrins NP Coulon Mireille 


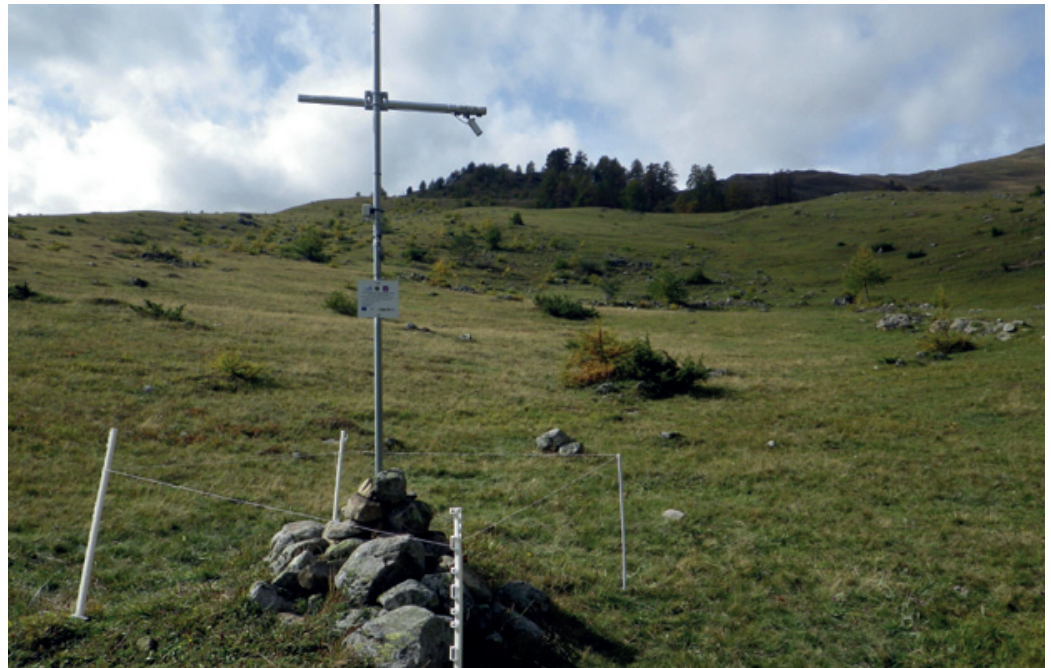

Figure 8 - Monitoring devices in mountain pastures. (C) Ecrins NP Clotilde Sagot

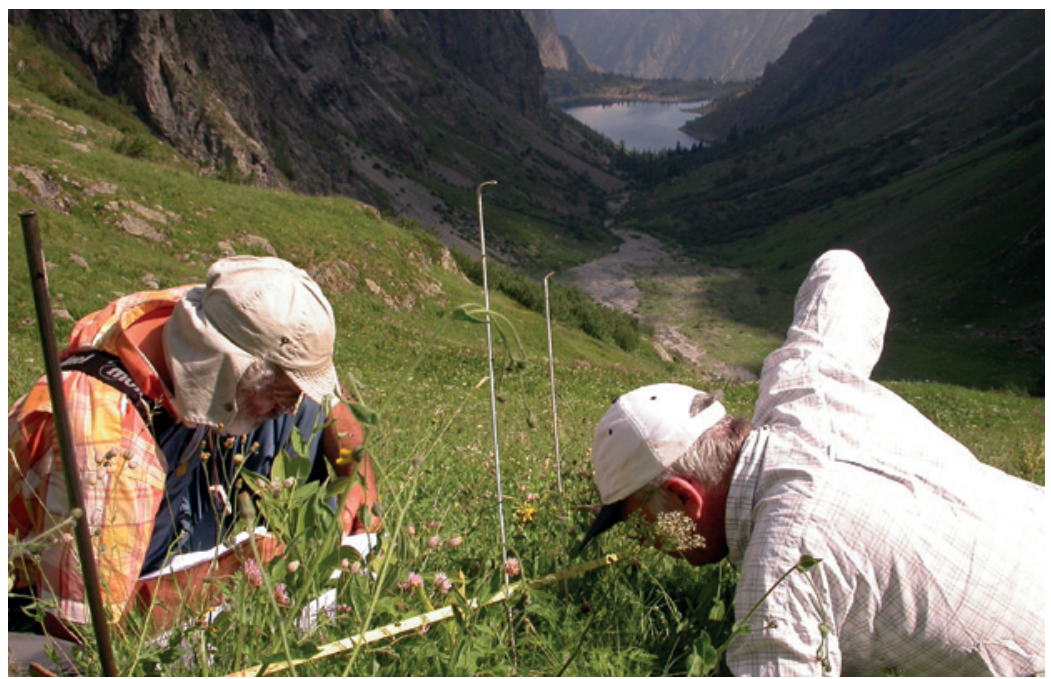

Figure 9-Work on one of the 30 permanent vegetation transects. (C) Ecrins NP Denis Fiat

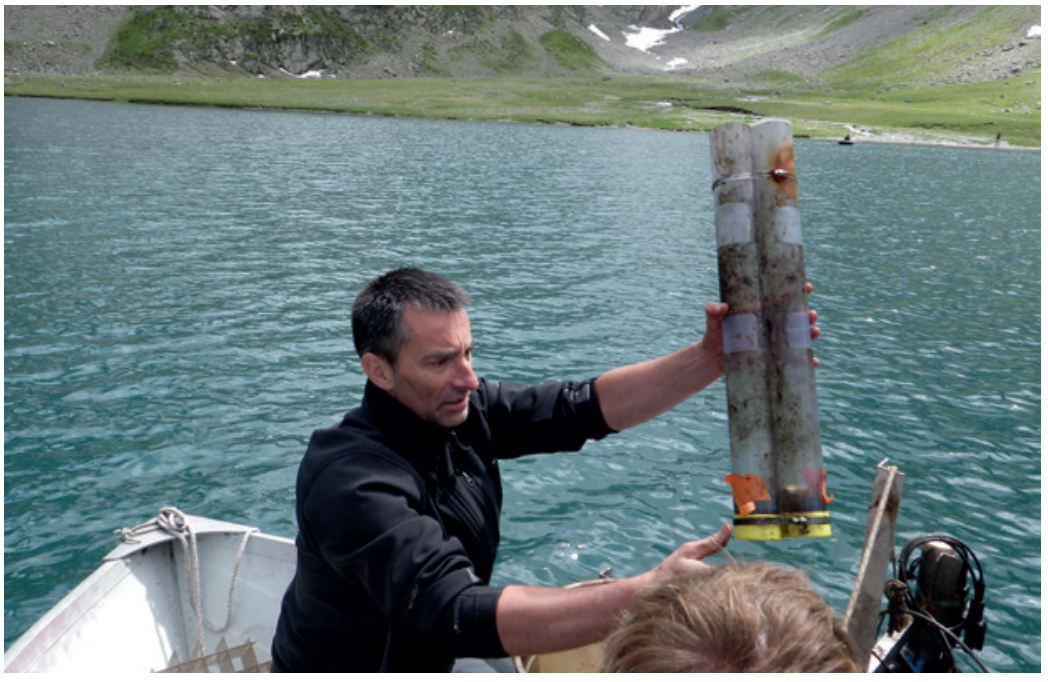

Figure 10 - Research at the Lac de la Murelle. (C) Ecrins NP Clotilde Sagot toring allow us to keep track of very localized vegetation changes.

In addition, since 2000, researchers have visited 124 representative sites of the park every five years (Figure 9) to observe the dynamics of vegetation cover (physiognomy) and of land use. Vegetation samples are collected at these sights each year, which enables a better understanding of vegetation changes on the scale of the entire NP. As is the case for other monitoring programmes, once changes have been observed, the difficulty lies in disentangling the impact of climate change from that of land-use changes.

\section{An Alpine network of high-altitude lakes}

A network of indicator lakes has been put in place across the Alps in the last ten years (Birck et al. 2013). For their part, Ecrins NP oversees the monitoring of four Alpine lakes where they measure water temperature, turbidity and oxygen levels, and also inventory the composition of phyto- and zooplankton populations (Cavalli \& Chappaz 1996 and Cavalli et al. 2001). This network of partners not only allows for the collection of temperature measurements in high-altitude bodies of water across the Alpine Arc, but also changes in the functioning of these lakes.

More extensive research is carried out at certain lakes, including the Lac de la Muzelle (in Venosc, Isère), where studies are hoping to expand our understanding of the consequences of human activity (local and regional impacts) and connections with climate change (Figure 10). One illustration of this is the atmospheric transport of persistent organic pollutants, such as polychlorinated biphenyls (PCBs), from valleys to high-altitude lakes. In partnership with Ecrins NP, the Laboratory of Molecular Chemistry and Environment (LCME, http://www.lcme.univsavoie.fr/index.php/fr/) and the Alpine Research Centre on Lake Ecosystems and Food Webs (CARRTEL, http://www6.dijon.inra.fr/thonon/) conducted a study to depict the transfer and the fate of atmospheric deposited PCBs in high-altitude Alpine lakes (Nellier et al. 2015a, b).

\section{Sediments core samples from the Muzelle}

Global changes have an important impact, among other things, on extreme events (floods and avalanches), water resources and mountain agriculture. These elements are not only of particular interest to the company Deux-Alpes Loisirs, which is responsible for the Deux-Alpes ski area, but also to the network of townships in the Oisans, the local government of Venosc and Ecrins NP. All of these actors collaborate in their study of the effects of global changes on mountain regions.

Laurent Fouinat, a $\mathrm{PhD}$ student at the Edytem Laboratory (http://edytem.univ-savoie.fr/), directs a retrospective study about the Deux-Alpes ski resort focusing on analyses of sediment core samples ex- 
tracted in 2012 and 2013 from three local lakes: Lauvitel, Muzelle and Plan (within the ski area).

A study of these core samples shows the past extent of the Glacier de la Muzelle and provides indications about former pastoral practices (Figure 11). Glaciers are very sensitive to climate change and the important decrease in size that we have observed during the last century is a departure from normal variation. At the Glacier de la Muzelle the lake situated below the glacier allows researchers to reconstitute past changes based on the RABD(I-band) reflectance spectroscopy index (Bolt et al. 2015). Essentially, when the glacier is larger, we see an increased production of glacial erosion in the sediment of the lake (Karlèn et al. 1976). At the beginning of the Middle Ages the Glacier de la Muzelle was about the same size as it is today. The extent of the glacier dramatically expanded between 1450 and 1900 during the Little Ice Age and was at its largest at the end of this period.

At the same time, studies of the sediment core samples show the presence of coprophilous fungi indicative of grazing (Ethienne et al. 2013) that demonstrate the evolution of the practice in the area. Grazing began in earnest around 1750, which marked a temporary period of glacial retreat. Grazing continued at a moderate pace until the last advance of the glacier when, in the $19^{\text {th }}$ and $20^{\text {th }}$ centuries, grazing reached exploitation levels on a par with what is seen today. Past glacial retreat and the current period of warming have permitted use of the lake and its surroundings for pasturing.

\section{High-altitude environments}

Climate change has an especially significant effect on high-mountain environments, illustrated well by glacial melt and the disappearance of snowfields.

Special attention is also being paid to wetlands for example, those with bicoloured sedge (Carex bicolor), snow beds and vascular plants growing at very high elevation, especially on south exposed cliffs (Vertical Ecology project) (Dentant \& Lavergne 2013). Ongoing measurement of physical and biological traits allows for tracking changes in these environments and how plants cope with extreme environments.

These analyses can also be compared to historical data. Plant distribution can be studied through the use of photographs, postcards and accounts from the first alpinists.

\section{Arctic-Alpine species}

Several research projects examine how particular species respond to environmental changes. As part of the conservation network Flore Alpes Ain, the NP oversees the monitoring of several rare and endangered plant species. Those located in areas of extreme cold and altitude are arctic-alpine species. Locating these species and tracking their prevalence and density helps to detect plant species loss and turnover and animal foraging activity in response to a changing climate (Figure 12).

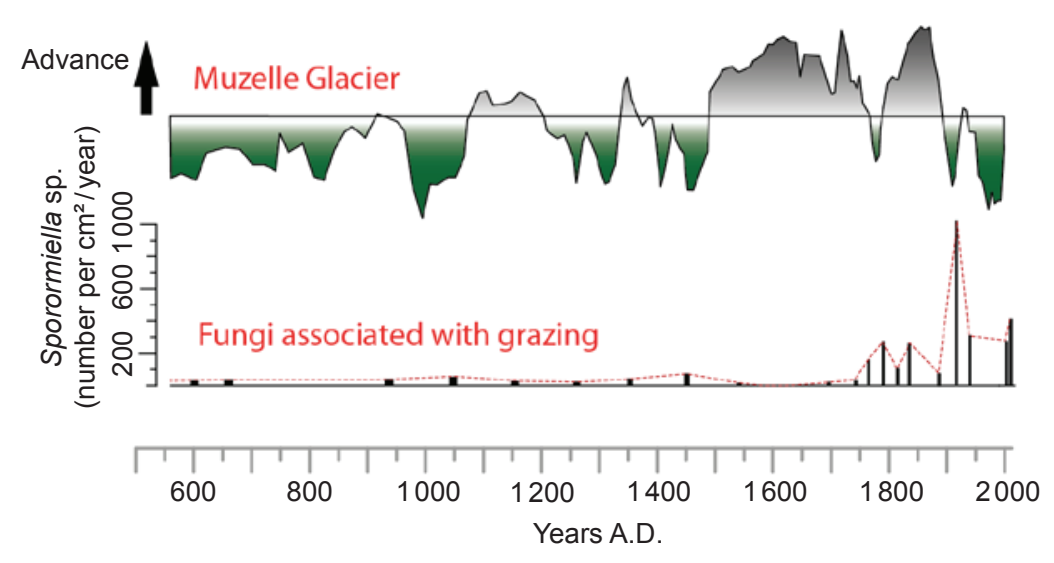

Figure 11 - Extend of the Muzelle Glacier. (C) EDYTEM Laurent Foninat

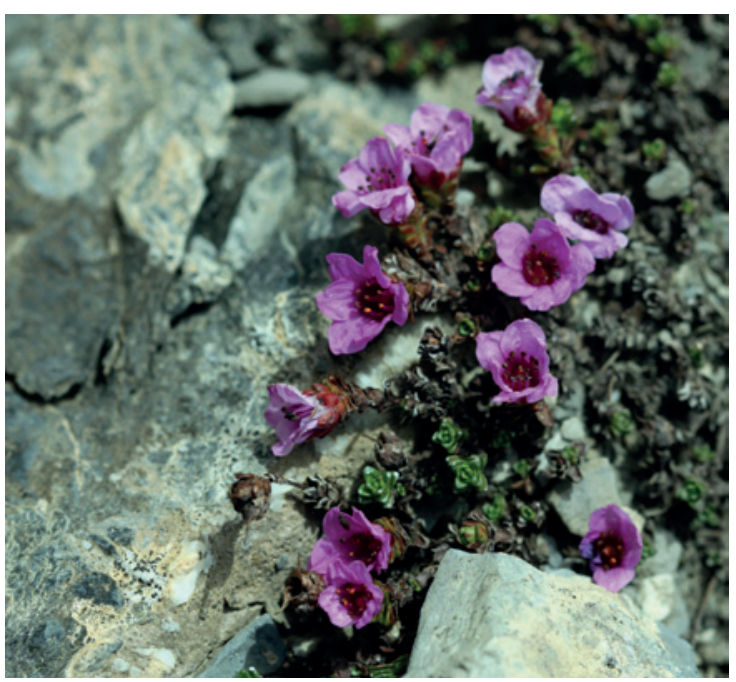

Figure 12 - Saxifraga oppositifolia. (C) Ecrins NP Cédric Dentant

In terms of fauna, the rock ptarmigan (Lagopus muta), Figure 13, is an especially emblematic and highpriority species. Its declining population concerns the entire mountain community (parks, naturalists, hunters and scientists), and raises important questions about the implementation of possible mitigation strategies to help stabilize rock ptarmigan populations.

The mountain hare (Lepus timidus), Figure 14, is another heritage species experiencing both the effects of climate change and competition from the European hare, which may extend its territory into alpine zones (Bouche 1998; Bisi et al. 2013; Rhenus et al 2013). If this happens the mountain hare population could experience introgressive hybridization with its larger competitor.

Ecrins NP has developed a capture, mark, recapture (CMR) protocol (Bouche et al. 2014) that implements the tools used by the National Hunting and Wildlife Agency (ONCFS, http://www.oncfs.gouv.fr/) in the Ristolas Reserve to collect and genetically analyse scat. Using scat samples, scientists can estimate the abundance of populations, area use and survival rates. This area of study is one of the fundamental aspects of 


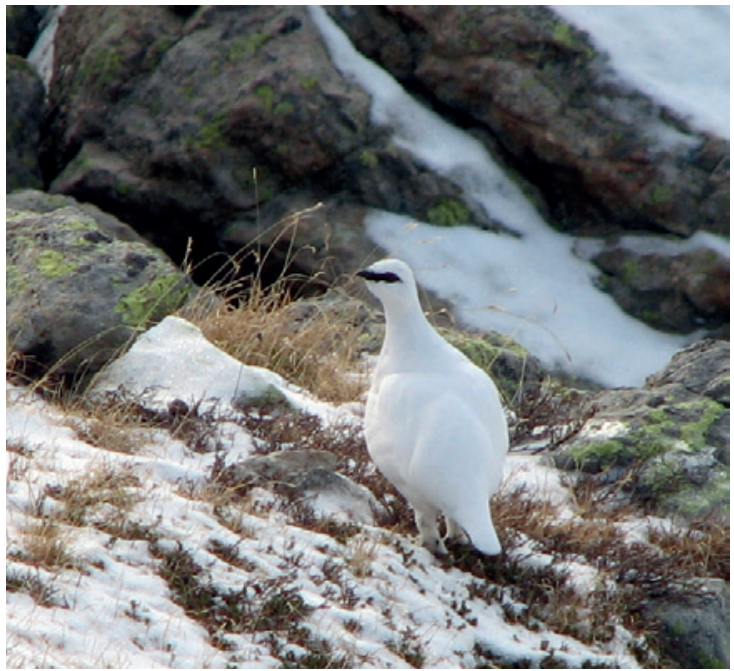

Figure 13 - Lagopus muta. (C) Ecrins NP Christophe Albert

long-term monitoring and is also of special interest to many social actors (hunting federations and naturalists) for whom the mountain hare represents an important part of their heritage.

\section{Ecrins NP as a research venue}

Ecrins NP is also an important area for research, in which it actively participates. The park's territory is included within the LTER France, a collaboration project created by the French National Centre for Scientific Research (CNRS) and the National Research Institute of Science and Technology for Environment and Agriculture (IRSTEA). LTER-Alpes is an umbrella for multidisciplinary projects focusing on the dynamics of social-ecosystems in the French Alps.

In the Diversitalp project - supported by the French National Research Agency (ANR) - the objective is to understand plant species responses to environmental change in terms of area of distribution, type of niche, and phenotypical expression as measured by functional traits. This understanding should allow, among other things, for predictions about how various species will respond to changes in climate and land use (Dullinger et al. 2012; Gehrig et al. 2007; Gottfried et al. 2012). Different models of vegetation evolution have been created using climate scenarios outlined by the IPCC (Boulangeat et al. 2014; Thuiller et al. 2014). In response to a call for projects by the Programme for the Management and Impacts of Climate Change (GICC), Sandra Lavorel of the LECA in Grenoble heads the SECALP programme (Adaptation of the Alpine territories to increasing droughts in the context of global change) with the goal of "analysing the possibilities of semi-natural mountain territories and their actors in responding to climate change, particularly in light of climate change" (Balent et al. 2015). This work has helped to create numerous different adaptation scenarios ac-

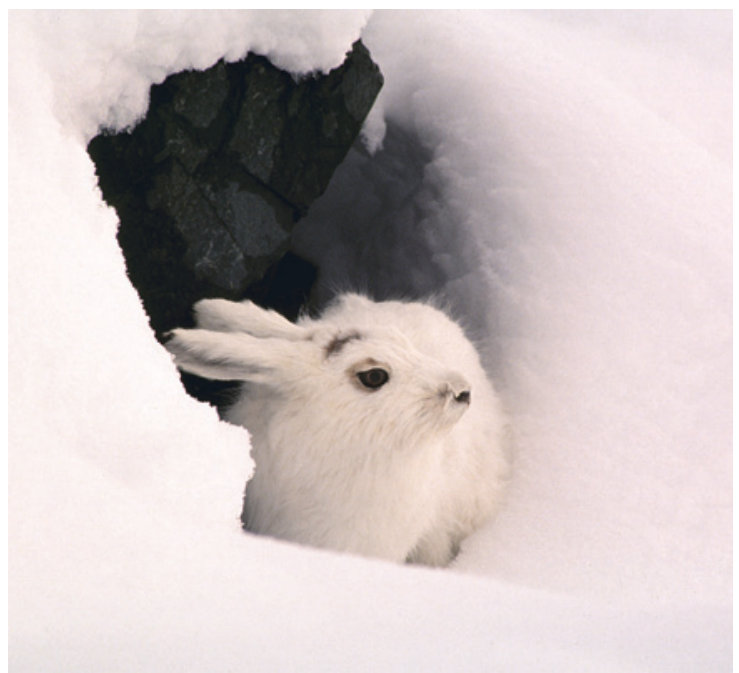

Figure 14 - Lepus timidus. (C) Ecrins NP Robert Chevalier

cording to drought levels experienced by farmers in the Haute Romanche.

Finally, the ongoing analysis of sediment core samples in high-altitude lakes in the Oisans allows researchers to retroactively observe and measure evolutions in phenomena linked to watershed dynamics (erosion, pollutants, vegetation, etc.) and to infer past climate conditions on the scale of multiple thousands of years. Like pollen or charcoal, which stay locked up in the soil, these sedimentary archives constitute an important source of information for discovering and understanding climate and changes over the course of the past two centuries.

Much of the data collected will also be contributed to international long-term observation networks such as the International Long-Term Ecology Research (ILTER) or the World Glacier Monitoring Service (WGMS).

\section{Acknowledgements}

Thanks go to Hillary Gerardi for the quality of her translation.

\section{References}

Balent, G., S. Lavorel, G. Loucougaray, G. Bertoni, I. Boisdon, M. Capitaine, M. P. Colace, L. Dobremez, A. Gibon, P. Gos \& X. Mesmin 2015. Ecological intensification prospects of fodder services provided by pastures of French mountains. A comparative analysis. Fourrages 221: 3-14.

Birck, C., I. Epaillard, M.F. Leccia, C. Crassous, A. Morand, C. Miaud, C. Bertrand, L. Cavalli, S. Jacquet, P. Moullec, R. Bonnet, C. Sagot, E. Franquet, Y.M. Nellier, M. E. Perga, N. Coffin, C. Pignol, E. Malet, E. Naffrechoux, C. Giguet-Covex, I. Jouffroy-Bapicot, D. Etienne, L. Millet, P. Sabatier, B. Wilhelm, B. Perren \& F. Arnaud 2013. Sentinel lakes: a network for 
the study and management of mountain lakes in the French Alps and in Corsica. eco.mont 5-2: 63-69.

Bisi, F., M. Nodari, N.M. Dos Santos Oliveira, F. Ossi, E. Masseroni, D.G. Preatoni, L.A. Wauters \& A. Martinoli 2013. Habitat selection and activity patterns in Alpine mountain hare (Lepus timidus varronis). Mammalian Biology 78: 28-33.

Boldt, B.R., D.S. Kaufman, N.P. McKay \& J.P. Briner 2015. Holocene summer temperature reconstruction from sedimentary chlorophyll content, with treatment of age uncertainties, Kurupa Lake, Arctic Alaska. Holocene 25: 641-650.

Bouche, M. 1988. Contribution à l'étude éco-éthologique du lièvre variable dans le massif des Ecrins. Document scientifique du Parc national des Ecrins.

Bouche, M \& G. Farny 2014. Le Lièvre variable dans le parc national des Ecrins : la génétique au service des gestionnaires de l'espace. Rapport interne Ecrins NP.

Boulangeat, I., D. Georges, C. Dentant, R. Bonet, J. Van Es, S. Abdulhak, N.E. Zimmermann \& W. Thuiller 2014. Anticipating the spatio-temporal response of plant diversity and vegetation structure to climate and land use change in a protected area. Ecography 37: 1230-1239.

Bourdeau, P. 2006. Mountain, field of the game and stakes; debates about future of mountaineering and sports of nature. Revne De Geographie. Alpine-Journal of Alpine Research 94: 121-121.

Bourdeau, P. 2009. Examining innovation in the Alps at the local scale: A region on the move, the "Pays des Ecrins". Revue De Geographie. Alpine-Journal of Alpine Research 97-1: 36-52.

Cavalli, L. \& R. Chappaz 1996. Diet, growth and reproduction of the Arctic charr in a high alpine lake. Journal of Fish Biology 49: 953-964.

Cavalli, L., A. Miquelis \& R. Chappaz 2001. Combined effects of environmental factors and predatorprey interactions on zooplankton assemblages in five high alpine lakes. Hydrobiologia 455: 127-135.

Choler, P. 2015. Growth response of temperate mountain grasslands to inter-annual variations in snow cover duration. Biogeosciences 12: 3885-3897.

Dentant, C. \& S. Lavergne 2013. Plantes de haute montagne : état des lieux, évolution et analyse diachronique dans le massif des Ecrins (France). Bulletin de la Société Linnéenne de Provence 64 : 83-98.

Dobremez, L., B. Nettier, J.-P. Legeard, B. Caraguel, L. Garde, S. Vieux, S. Lavorel \& M. Della-Vedova 2014. Sentinel Alpine Pastures: An original programme for a new form of shared governance to face the climate challenge. Revue De Geographie. Alpine-Journal of Alpine Research 102-2: 2-10.

Dumas, D., D. Fiat \& H. Cortot 4-7 octobre 2011: Fonctionnement bydrologique du Lawitel (Parc national des Ecrins, France). Poster présenté au colloque des Zone Ateliers, Rennes.

Dullinger, S., A. Gattringer, W. Thuiller, D. Moser, N. E. Zimmermann, A. Guisan, W. Willner, C. Plutzar, M. Leitner, T. Mang, M. Caccianiga, T. Dirnbock, S.
Ertl, A. Fischer, J. Lenoir, J. C. Svenning, A. Psomas, D. R. Schmatz, U. Silc, P. Vittoz \& K. Hulber 2012. Extinction debt of high-mountain plants under twenty-first-century climate change. Nature Climate Change 2: 619-622.

Etienne, D., B. Wilhelm, P. Sabatier, J.-L. Reyss \& F. Arnaud 2013. Influence of sample location and livestock numbers on Sporormiella concentrations and accumulation rates in surface sediments of Lake Allos, French Alps. Journal of Paleolimnology 49: 117-127.

Gardent, M., A. Rabatel, J.P. Dedieu \& P. Deline 2014. Multitemporal glacier inventory of the French Alps from the late 1960s to the late 2000s. Global and Planetary Change 120: 24-37.

Gehrig-Fasel, J., A. Guisan \& N.E. Zimmermann 2007. Tree line shifts in the Swiss Alps: Climate change or land abandonment? Journal of Vegetation Science 18: 571-582.

Gottfried, M., H. Pauli, A. Futschik, M. Akhalkatsi, P. Barancok, J.L.B. Alonso, G. Coldea, J. Dick, B. Erschbamer, M.R.F. Calzado, G. Kazakis, J. Krajci, P. Larsson, M. Mallaun, O. Michelsen, D. Moiseev, P. Moiseev, U. Molau, A. Merzouki, L. Nagy, G. Nakhutsrishvili, B. Pedersen, G. Pelino, M. Puscas, G. Rossi, A. Stanisci, J.P. Theurillat, M. Tomaselli, L. Villar, P. Vittoz, I. Vogiatzakis \& G. Grabherr 2012. Continent-wide response of mountain vegetation to climate change. Nature Climate Change 2: 111-115.

Karlen, W. 1976. Lacustrine sediments and treelimit variations as indicators of Holocene climatic fluctuations in Lappland, Northern Sweden. Geografiska Annaler Series a-Physical Geography 58: 1-34.

Nellier, Y.-M., M.-E. Perga, N. Cottin, P. Fanget, E. Malet \& E. Naffrechoux 2015. Mass budget in two high altitude lakes reveals their role as atmospheric PCB sinks. Science of the Total Environment 511: 203-213.

Nellier, Y.-M., M.-E. Perga, N. Cottin, P. Fanget \& E. Naffrechoux 2015. Particle-Dissolved Phase Partition of Polychlorinated Biphenyls in High Altitude Alpine Lakes. Environmental Science \& Technology 49: 9620-9628.

Rehnus, M., L. Marconi, K. Hacklaender \& F. Filli 2013. Seasonal changes in habitat use and feeding strategy of the mountain hare (Lepus timidus) in the Central Alps. Hystrix-Italian Journal of Mammalogy 24: 161-165.

Thuiller, W., M. Gueguen, D. Georges, R. Bonet, L. Chalmandrier, L. Garraud, J. Renaud, C. Roquet, J. Van Es, N.E. Zimmermann \& S. Lavergne 2014. Are different facets of plant diversity well protected against climate and land cover changes? A test study in the French Alps. Ecography 37: 1254-1266.

\section{Authors}

Richard Bonet, Parc national des Ecrins; Fabien Arnaud, Laboratoire Environnement, DYnamiques et Territoires de la Montagne (EDYTEM), Université Savoie Mont Blanc; Xavier Bodin, EDYTEM, 
Université Savoie Mont Blanc; Michel Bouche, Parc national des Ecrins; Isabelle Boulangeat, Laboratoire d'ECologie Alpine (LECA), Université Grenoble Alpes; Philippe Bourdeau, Institut de Géographie Alpine, Université Grenoble Alpes; Martial Bouvier, Parc national des Ecrins; Laurent Cavalli, Institut Méditerranéen de Biologie et d'Ecologie marine et continentale, Aix*Marseille Université; Philippe Choler, LECA, Université Grenoble Alpes; Anne Delestrade, Centre de Recherche sur les Ecosystèmes d'Altitude; Cédric Dentant, Parc national des Ecrins; Dominique Dumas, UMR 5600: environnement, ville et sociétés, Université Lyon 3; Laurent Fouinat, EDYTEM, Université Savoie Mont Blanc; Marie Gardent, EDYTEM,
Université Savoie Mont Blanc; Sébastien Lavergne, LECA, Université Grenoble Alpes; Sandra Lavorel, LECA, Université Grenoble Alpes; Emmanuel Naffrechoux, Laboratoire Chimie Moléculaire et Environnement, Université Savoie Mont Blanc; Yann Nellier, Laboratoire Chimie Moléculaire et Environnement, Université Savoie Mont Blanc; Marie-Elodie Perga, Institut National de la Recherche Agronomique; Clotilde Sagot, Parc national des Ecrins; Olivier Senn, phyto-ecologist; Emmanuel Thibert, Institut national de recherche en sciences et technologies pour l'environnement et l'agriculture; Wilfried Thuiller, LECA, Université Grenoble Alpes. 